\title{
Translating Representations: Orientalism in the Colonial Indian Province of Bengal (1770s-1830s)
}

Emily Larocque

\begin{abstract}
The late 18th century to early 19th century British conquest into the Indian province of Bengal provides a fascinating study of the influence of translation and printing on the colonial relationship. Translation, as a form of representation, is yet another lens through which we can analyze Edward Said's concept of Orientalism (colonizer/colonized relationships) and witness the complexities and consequences that can result when individuals reinforce and/or subvert these 'relations of power.'
\end{abstract}

Since Edward Said's work on Orientalism first appeared in 1978, scholars have employed his way of conceiving colonial relationships created through representations of the other. ${ }^{1}$ Said examines the age of imperialism and notions of otherness, and argues that western scholars constructed a stereotyped image of what they viewed as the "Orient." The Orient as a construct focused on the exotic nature of the cultures. Said suggests the work of these scholars supported and enabled colonialism. ${ }^{2}$ Said once described his theory on Orientalism as

a way of coming to terms with the Orient that is based on the Orient's special place in European Western Experience. The Orient is not only adjacent to Europe; it is also the place of Europe's greatest and richest and oldest colonies, the source of its civilizations and languages, its cultural contestant, and one of its deepest and most recurring images of the Other. In addition, the Orient has helped to define Europe (or the West) as its contrasting image, idea, personality, and experience. Yet none of this Orient is merely imaginative. The Orient is an integral part of European material civilization and culture. Orientalism expresses and represents that part culturally and even ideologically as a mode of discourse with supporting institutions, vocabulary, scholarship, imagery, doctrines, even colonial bureaucracies and colonial styles. ${ }^{3}$

Similarly, Orientalism provides a useful way of conceptualizing translation and its place in colonial endeavors. Translation is arguably another mode of representation created by the elite of the Indian colonial bureaucracy. The very process of moving texts encoded in one culture and language and transferring it to another cultural reality involves representing the source culture to the target; it requires reducing the text to its elementary meaning and recasting it in a way that is meaningful to the target culture. Translation freezes the text in its

\footnotetext{
${ }^{1}$ Edward W. Said, Orientalism (New York: Pantheon Books, 1978).

2 Note: This brief summary was taken from a general reading of Edward Said's Orientalism. For more information and further readings see Said's complete text.

3 Edward Said, "Orientalism: A Brief Definition," Political Discourse-Theories of Colonialism and Postcolonialism, accessed November 19, 2011, http://www.postcolonialweb.org/poldiscourse/pol11.html.
} 
expression in one cultural moment, and then transfers it to another cultural context where the clock starts again, but on a different time line. In Edward Said's essay, "Traveling Theory Reconsidered," he states "the first time a human experience is recorded and then given a theoretical formulation, its force comes from being directly connected to and organically provoked by real historical circumstances. Later versions of the theory cannot replicate its original power; because the situation has quieted down and changed, the theory is degraded and subdued..." (emphasis added). In many ways, translation allows theories and ideas to travel. Although Said's essay deals more with the movement of ideas across time and place, I would argue that the movement of translations is just as crucial. Translations may lose the types and expressions of force they had in their original culture, but translation, or the 'traveling' of texts, restarts the clock, giving translations different meaning and force in newfound cultural contexts. Translations are naturally documents deemed significant, in that one would not undertake the arduous journey of translation without having an important purpose in mind. Thus the translation becomes no less important in its travels. Rather, the cultural meanings and symbols it acquires through its movements teach us that translation brings with it a world of meanings and consequences.

Translation gained a particular meaning and importance in Britain's colonial enterprises during the late $18^{\text {th }}$ and early $19^{\text {th }}$ century. Using the word 'enterprise' is no stretch, as the East India Company doubled as the governing body in India until the loss of its monopoly following the Charter of $1813 .{ }^{5}$ Translation became the right hand of the colonizing effort, tying directly into the commercial interests of the East India Company. Colonialism as a mercantilist market system is especially interesting to examine because it involved all aspects of the colony being brought under the control of the mother country. Translation was necessary for administrative and governing purposes and later for the co-opting of the elite through an intellectual colonialism of sorts when the focus was put more on improvement and education in the early $19^{\text {th }}$ century. ${ }^{6}$ Translation as representation divides between two central arguments: is translation primarily a portrayal of the other, or is it a more complex relationship where self-representation to the other is the focus? Tesjaswini Niranjana sees colonialism as a largely exploitive control mechanism, arguing translation is a mode of representation enabling colonized subjects to eventually accept their role as subjects as natural. ${ }^{7}$ Conversely, social theorist Gauri Viswanathan argues that the colonizing enterprise and translation actually served to feed particular representations of the British to their colonial subjects in India in order to establish the image of the benevolent and just British ruler governing the Indian people. ${ }^{8}$ In order to examine translation and how it functioned as a mode of representation (whether as representing the other or the self), I will focus on the geographic area of the Bengal province and examine the colonial translation enterprise. I will conclude with a brief case study of British missionary William Carey to India (1790s-1830s) and his work as a translator, professor, and Orientalist in the Bengali language as a case study.

\footnotetext{
${ }^{4}$ Simon During (ed.), The Cultural Studies Reader, 2nd edition (London: Routeledge, 1999), 242.

5 Tejaswini Niranjana, "Translation, Colonialism, and the Rise of English," Economic and Political Weekly (April 14, 1990), 777.

6 Ibid., 778.

${ }^{7}$ Ibid.

${ }^{8}$ Gauri Viswanathan, "Currying Favor: The Politics of British Educational and Cultural Policy in India, 18131854," Social Text (Autumn 1988), 86.
} 


\section{Background: Early Translation Enterprises in India}

The intellectual, spiritual, and economic colonialism and conquest of India was not unique to Britain. In the "Early History of Bengali Printing," M. Siddiq Khan observes that as early as 1556, Jesuits established presses in the Portuguese colony of Goa to enable the spread of Christian texts, starting with translation into the Tamil language. The Portuguese had well established their trade relations on the western coast of India; tradesmen and religious figures gradually made inroads into other parts of India and by 1581 trade boats made yearly visits to Bengal. ${ }^{9}$ The $17^{\text {th }}$ century saw Jesuits fluent in indigenous languages, constructing "vocabularies, a grammar, a confessionary and prayers." "Later Bengalis did not have printing presses due to what Siddiq Khan sees as a "lack[... of $]$ the education and the type of social organization necessary to realize the potential benefit of printing on their own language and literature" 11

The East India Company consolidated British power in the province of Bengal following its victory in the 1757 Battle of Plassey and, by 1752, had satisfactorily taken over governance of the province. ${ }^{12}$ However, ensuring the longevity and legitimacy of British rule and commercial effectiveness would require more than just force and guns. British powers had to take on a policy of intellectual colonialism, striking a fine balance between exploitation and promotion of the people's language and culture. ${ }^{13}$

\section{Orientalism, Anglicism, and Mixed Styles of Governance}

Viswanathan conceptualizes the East India company's approach to governance in the period of the 1750s-1813 as falling into three main thematic points: a focus on Orientalism, a shift to Anglicism, and a conclusion in a mixed governance style making use of the most effective parts of each approach. The Orientalist approach to governing focused on disrupting the Indian way of life as little as possible to minimize reasons for revolt and discontent among the indigenous population. Orientalism as an "official policy" was adopted between 17741785 under Governor General Warren Hastings. ${ }^{14}$ Viswanathan views this policy as a direct response to the exploitive and distant nature between government/traders and Indians. ${ }^{15}$ The policy necessitated what Viswanathan calls "reverse acculturation," or a system of government where its administrators fit seamlessly into the fabric of daily indigenous life by changing the English approach rather than forcing foreign policies on the colonized subject. ${ }^{16}$ Administrators worked through existing institutions rather than enforcing new ones.

Orientalism's expression in translation was seen through the upsurge in popularity of texts from India's past. Niranjana shows that although Europeans generally regarded the glorious Indian past steeped in mysticism with romantic ardor, they conversely saw contemporary Indians as degraded, having little in common with their predecessors. ${ }^{17}$ One particular poem popular in Europe (as discussed by Niranjana) was a European-made "A Hymn to Surya"

\footnotetext{
${ }^{9}$ M. Siddiq Khan, “The Early History of Bengali Printing," The Library Quarterly (January 1962), 51.

${ }^{10}$ Ibid., 52.

11 Ibid., 53.

12 Ibid.

13 Ibid.

14 Viswanathan, "Currying Favor," 87.

15 Ibid.

16 Ibid., 88.

${ }^{17}$ Niranjana, "Translation, Colonialism, and the Rise of English," 773.
} 
that placed the translator in the place of a textual messiah. The translator had come to India to draw "Orient knowledge from its fountains pure" (emphasis added), and release it from its wretched contemporary form. ${ }^{18}$ Thus the English perceived themselves as having a mission to "purify" indigenous culture, using translation as a means to correctly and more faithfully represent the magnificent Indian past.

From a legal point of view, translation was also exceedingly useful in the realm of administration. For example, by 1777, the introduction to a published grammar pressed for East India Company employees to have a command of the local language of administration (Persian) because of the colonial administration's distrust for Indian interpretation. ${ }^{19}$ Siddiq Khan gives numerous examples of legal texts printed during the late $18^{\text {th }}$ century, attesting to the extent of this colonial anxiety. ${ }^{20}$ Knowledge of the local language allowed colonial authorities to interpret and "verify" indigenous laws on their own terms. ${ }^{21}$ Legal interpretation translated legal codes from its source culture, encoding it in British understanding. As western interpretations were viewed as more trustworthy and legitimate than the 'supsect' indigenous interpretations, Niranjana sees this type of relationship as reinforcing hierarchical relations of power. ${ }^{22}$ Oientalist colonial administration did not last forever as some distrusted governing through existing indigenous institutions. This anxiety led to a reactionary movement in support of Anglicization, which would bring about different consequences for translation.

When leadership changed from Hastings to Lord Cornwallis in 1786, the new governor abandoned the policy of Orientalism. He believed the increasing corruption in the East India Company was due to the "vices" and "temptations" inherent to Indian culture. Use of Indian institutions and modes of government was seen as having caused the corruption, leading to questioning and criticism at home for the colonial enterprise. ${ }^{23}$ Cornwallis discouraged giving positions to indigenous and did nothing to promote (nor discourage) Oriental literature. Viswanathan sees this period as the clearest enunciation of the colonizercolonized relationship of power. ${ }^{24}$

The mixed approach came into being with the next shift of governor-generals. The change over to the Marques of Hastings in 1812 brought with him the realization that supporting policies of Orientalism actually better solidified the success of the colonial enterprise rather than alienating the Indian elite. Hastings, among others who followed the same principles, used a mixture of Cornwallis' conservative desire to solidify the morality of the enterprise and a decidedly Orientalist view in regards to ensuring the longevity of their administration. ${ }^{25}$ The newest expression of Orientalism in colonial India meant enacting a policy of indirect rule where the indigenous elite were co-opted into ruling with the British, facilitating the government and policies of the colonizer. ${ }^{26}$ The introduction of the Charter of 1813 opened up India to missionaries and free trade, naturally drawing religious eyes onto the moral character and the state of the soul of the indigenous person. Education thus became a hugely

18 Ibid., 775.

${ }^{19}$ Ibid., 774.

${ }^{20}$ Khan, "Early History of Bengali Printing," 56.

${ }^{21}$ Niranjana, "Translation, Colonialism, and the Rise of English," 775.

22 Ibid.

${ }^{23}$ Viswanathan, "Currying Favor," 88.

24 Ibid., 89.

25 Ibid.

26 Ibid., 90. 
important tool of encouraging the co-opted indigenous elite to adopt whole-heartedly the British style of governance. Niranjana shows that the drive to better educate the elite also came back to economic motivations; indigenous people would become more "advanced" and desirous of the "ingenious" products of Britain. ${ }^{27}$ Education led to the preference of English texts, encouraging some such as Macaulay to arrogantly believe that a few English books outweighed all the literature of the Indians. ${ }^{28}$ Ninranjana argues quite provocatively "European translations of Indian texts prepared for a Western audience provided to the educated Indian a whole range of Orientalist images...[The colonial subject] preferred, because of the symbolic power attached to English[,] to [...] access[...] his own past through the translations and histories circulating through colonial discourse." 29 In this way, translation became a natural method for colonized subjects to create self-conceptualizations and to re-create ways of accessing status, especially with the replacement of the administrative language of Persian with English as the official language of India in $1835 .^{30}$

\section{Case Study: William Carey-Translator, Professor}

So far, the study of the colonial dialectic of power between colonizer/colonized in the Bengali province has focused on how the East India Company's policies enhanced British control. What remains to be seen, however, is what impact this actually had among the people. How did individuals in India respond to the changing colonial situation and make it work for themselves? Khan argues that much of the efforts on the part of colonial administration to streamline and entrench their own governance actually ended up promoting Bengali literature. ${ }^{31}$ It was said that upon Carey's arrival in Nabadwip, the cultural hub of Bengal province, there were only forty hand-written documents in Bengali. ${ }^{32}$ As discussed previously, Khan argues that the structure of Bengali society was not elaborate enough to support a well-developed printing press, nor did they recognize the benefit of printing and publishing works in their own language. ${ }^{33} \mathrm{I}$ would argue that this is less a reflection on the people and more so a reflection on the history of conquest in India. English eventually replaced Persian as the language of administration and status. Just as some indigenous elite accessed social power by depending on English, I suspect a similar process took place in earlier years when Persian was the bureaucratic language. Bengali thus would not have been viewed by the people as a validated way to express high thought.

\footnotetext{
${ }^{27}$ Niranjana, "Translation, Colonialism, and the Rise of English," 777.

28 Ibid., 778.

${ }^{29}$ Ibid.

30 Oleg Grabar, “"Islamic arts," Encyclopadia Britannica, Encyclopadia Britannica Online. Encyclopædia Britannica, 2011, http://www.britannica.com.login.ezproxy.library.ualberta.ca/EBchecked/topic/295642/Islamic-arts (accessed April 11, 2011).

31 Khan, "Early History of Bengali Printing," 54.

32 Ibid., 53.

33 Ibid.
} 
In answer to Carey's complaint of finding a few manuscripts, Carey published a grammar, translations of the Bible, and a translation of the epic poem Ramayana among texts. H.H. Wilson, a "Boden Professor of Sanscrit in the University of Oxford, Member of the Royal Asiatic Society, and of the Asiatic Societies of Bengal, Paris," wrote some interesting comments regarding Carey and his translation work. Wilson credited Carey with the establishment of a press that, aside from biblical translation printing, "was devoted to the printing of the first efforts of native literary talent." ${ }^{34}$ Specifically, Carey published various Orientalist translations "from Sanscrit into Bengali, as the Hitopadesa, the Buttees Sinhasan, and others, [...] in 1801. In 1802 the early translations of the Ramayana and the Mahabharat, were published." Wilson said that "the indirect promotion of Bengali literature,

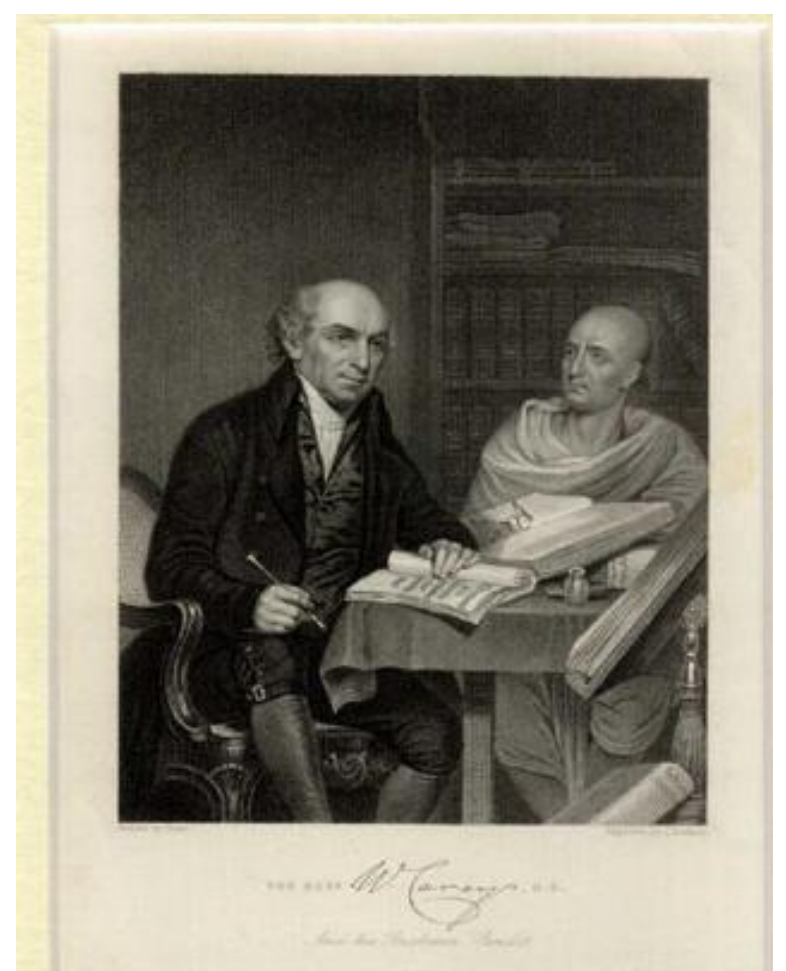

Figure 1: "The Revd. W. Carey, D.D. and his Brabmin Pundit (William Carey; Mritunjaya)"

http:/ / wnw.npgprints.com/ image.php?id $=24810$

effected by the example and impulse of the press of Serampore, ha[d] been still more important, and of late years ha[d] rendered it necessary for the directors of that establishment to originate compositions in the language of Bengal" (emphasis added). ${ }^{35}$ Carey also taught Bengali to and literature at Fort William College, an instrumental institution in creating an English bureaucracy educated and able in the Bengali language. Interestingly, the college made use of Indian pundits to help with education. In Figure 1, William Carey is pictured with Pundit Mritunjaya. The image portrays the pundit holding up Carey's books, looking to Carey as though for guidance. Although the power relation is obvious, the Pundit is portrayed as holding his head high in dignity. Sitting with Carey in his study and holding books (the symbol of Carey's works in India) translates into a position of importance and status for Mritunjaya. According to Wilson, "Mrityunjaya pundit was especially attached to the service of Dr. Carey as professor in the college, and was held by him in high and deserved estimation. He is the individual whose portrait is included in the picture taken by Mr. Home...He continued until his death associated with his master and friend in useful literary occupations." 36 This fit into the mixed approach to governance supported by Hastings where indigenous culture was viewed as the "soil" upon which the new government would flower. ${ }^{37}$

\footnotetext{
34 Eustace Carey, Francis Wayland, Jeremiah Chaplin, and William Carey, Memoir of William Carey, D, D (London: Jackson and Walford, 1837), 602.

35 Ibid., 602.

36 Ibid., 597.

37 Viswanathan, "Currying Favor," 90.
} 
Carey's indirect encouragement of the Bengali language through printing and publication actually helped improve the situation of indigenous culture and language. Along with many other Orientalists who preferred the type of Bengali that demonstrated more Sanskrit in its origins, Carey helped promote this type of Bengali language and helped to validate it as a meaningful way to textualize language. ${ }^{38}$ One of the most powerful examples of the indirect effects of colonial translation and printing are the comments by Baboo Ram Comol Shen, an indigenous scholar who had also compiled a dictionary.

I must acknowledge, here, that whatever has been done towards the revival of the Bengali language, its improvement, and, in fact, the establishment of it as a language, must be attributed to that excellent man Dr. Carey, and his colleagues, by whose liberality and great exertions many works have been carried through the press and the general tone of the language of this province has been greatly raised. ${ }^{39}$

H.H. Wilson stated: "No individual [was] better qualified than the talented native whose words [were] here cited, to appreciate accurately the share taken by Dr. Carey in the improvement of the language and literature of his country." 40 Baboo Ram Comol Shen's perception of Carey can be viewed in two ways: 1) as evidence of the power of colonialism translation to infiltrate the mind of the colonized person and to cause him/her to accept the representations created by translation as natural and acceptable; or 2) the subversion of colonial translation to benefit and enrich one's own language and culture. There is evidence that indigenous-controlled printing presses sprung up as the $19^{\text {th }}$ century got underway. ${ }^{41}$ One specific example shows that the indigenous printer Paunchanan took over the enterprise of his English mentor Wilkins, who had returned to England, making the business extremely profitable for himself. This same printer was eventually helped Carey print some of his publications. ${ }^{42}$

\section{Conclusion}

As this paper draws to a close, I feel there are more lingering questions than a clear idea about translation and its effect on colonial relationships of power. With study, it seems that interactions between individuals in the colonial system were far more complex than previously thought. Edward Said's Orientalism, for example, has been criticized for attributing too much power to the colonizer and reducing the colonized to a monolithic block sans-agency. In the introduction to Edward Said's essay, "Traveling Theory Reconsidered," the editor noted Said "does not distinguish between different kinds and moments in colonialism and the binary colonizer/colonized that he and Fanon use are far too simple. ${ }^{43}$ However, what is clear is that translation, as a form of representation, remains a powerful way of conceptualizing how colonial relationships can function. Translation can be both dangerous and beneficial. In studying representations through the lens of Orientalism, however, we must be careful not to divorce too much agency from the indigenous "other." It is clear that more research should be done in how Indians actually

\footnotetext{
38 Khan, "Early History of Bengali Printing," 53.

39 Baboo Ram Comol Shen, cited in Carey, Memoir, 597.

40 Ibid., 597.

${ }^{41}$ Khan, "Early History of Bengali Printing," 59-60.

42 Ibid, 59-60.

43 During, Cultural Studies Reader, 241.
} 
viewed the colonial enterprise of translation/printing. Was it useful to their lives and business? Was translation destructive to their culture? In much the same way, we cannot view British colonialism and translation as the only one that used intellectual conquest to support and entrench their empires. Rather, much like translation, it was a momentary expression of power relations that have transformed exceedingly over the centuries. 


\section{Bibliography}

Carey, Eustace, Francis Wayland, Jeremiah Chaplin, and William Carey. Memoir of William Carey, D, D. London: Jackson and Walford, 1837.

During, Simon (ed.). The Cultural Studies Reader. $2^{\text {nd }}$ edition. London: Routeledge, 1999.

Niranjana, Tejaswini. "Translation, Colonialism, and the Rise of English." Economic and Political Weekly, April 14, 1990.

Said, Edward W. Orientalism. New York: Pantheon Books, 1978.

Siddiq Khan, M. “The Early History of Bengali Printing.” The Library Quarterly (January 1962): 51-61.

Viswanathan, Gauri. "Currying Favor: The Politics of British Educational and Cultural Policy in India, 1813-1854.” Social Text (Autumn 1988): 85-104. 